\title{
CORRIGENDUM
}

\section{An ice core record of near-synchronous global climate changes at the Bølling transition}

Julia L. Rosen, Edward J. Brook, Jeffrey P. Severinghaus, Thomas Blunier, Logan E. Mitchell, James E. Lee, Jon S. Edwards and Vasileios Gkinis

Nature Geoscience 7, 459-463 (2014); published online 4 May 2014; corrected after print 13 June 2014.

In the version of this Article originally published, the last sentence in the caption of Fig. 4 should have read 'The most likely lead of temperature over methane emissions is $4.5_{-24}^{+21}$ years. This error has now been corrected in all online versions of the Article. 